DOI 10.15826/qr.2020.2.487

УДК 338.439(470.5)

\title{
PRIVATE TRADE IN THE MIXED ECONOMY OF THE URALS UNDER THE NEP*
}

Rev. of: Kilin, A. P. (2018). Chastnaya torgovlya i kredit na Urale v gody nepa: ekonomicheskie, politicheskie i sotsial'nye aspekty [Private Trade and Credit

in the Urals under the NEP: Economic, Political, and Social Aspects]. Yekaterinburg, Izdatel'stvo Ural'skogo universiteta. 606 p.

Vladimir Ilyinykh

Institute of History of the Siberian Branch of the Russian Academy of Sciences,

Novosibirsk, Russia

The author reviews Private Trade and Credit in the Urals under the NEP: Economic, Political, and Social Aspects: A Monograph by A. P. Kilin, which focuses on the topic of private trade under the NEP and considers it in a wider chronological context. The monograph analyses the NEP as a model of managing and regulating the economy, trade, and commodity turnover in the Urals. It also considers private trade as an object of state control, the credit system, social aspects of private enterprise under the NEP and the trading and intermediary activities of workers. The monograph provides a heterogeneous picture which enables the reader to gain a comprehensive idea of the NEP and the place private trade occupied in it. Of crucial historiographic importance is the author's conclusion that private trade was an organic part of the mixed economy's structure under the NEP and served to connect the producer, the consumer, different spheres of economy and economic setups.

Keywords: NEP; nepman; private capital; trade; credit; Urals.

Представлен анализ монографии А. П. Килина «Частная торговля и кредит на Урале в годы НЭПа: экономические, политические и социальные аспекты». В исследовании тематика частной торговли в условиях НЭПа встроена в более широкий проблемный и хронологический контекст. В монографии осуществлен анализ новой экономической политики как модели управления и регулирования экономики, торговли и товарооборота на Урале, частной торговли как объекта государственного регулирования, кредитной системы, социальных аспектов частнопредпринимательской деятельно-

* Citation: Ilyinykh, V. (2020). Private Trade in the Mixed Economy of the Urals under the NEP. In Quaestio Rossica. Vol. 8, № 2. P. 669-677. DOI 10.15826/qr.2020.2.487.

Цитирование: Ilyinykh V. Private Trade in the Mixed Economy of the Urals under the NEP // Quaestio Rossica. Vol. 8. 2020. № 2. P. 669-677. DOI 10.15826/qr.2020.2.487.

(C) Ilyinykh V., 2020

Quaestio Rossica • Vol. 8 • 2020 • № 2, p. 669-677 
сти в условиях НЭПа, торгово-посреднических практик рабочих. В книге представлена достаточно мозаичная картина, которая позволяет читателю получить репрезентативное представление о НЭПе и месте в нем частной торговли. Историографическое значение имеет вывод автора, что частная торговля органически вписывалась в структуру нэповской многоукладной экономики, служила связующим звеном между производителями и потребителями, различными секторами экономики и хозяйственными укладами.

Ключевые слова: НЭП; нэпман; частный капитал; торговля; кредит; Урал.

The NEP remains one of the key issues of post-Soviet historiography. However, academic attention has not always been equally intense, peaking during the 1990s. Nowadays, the issue is quite rarely the focus of scholarly attention. As a result, any new monographs examining the topic are of interest to academia. One such work is Private Trade and Credit in the Urals under the NEP: Economic, Political, and Social Aspects by the Ural researcher A. P. Kilin [Килин].

Private trade was a characteristic feature of the NEP and is recognised as one of its key institutional features. Without NEPmen, there was no NEP.

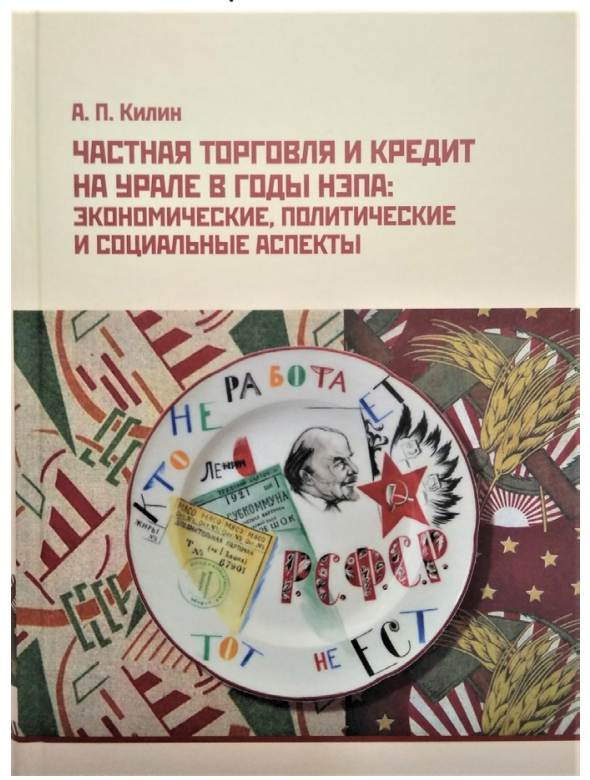

However, it is important to point out that private entrepreneurs not only defined the NEP but were also its collective actors. Their economic and social behaviour was the foundation for the changes made to the New Economic Policy by the government and conditioned its dynamics.

Of primary importance is the regional aspect of the topic; according to I. B. Orlov, this makes it possible to proceed from averages to a multitude of assessments [Орлов, с. 33]. For instance, E. V. Demchik's monograph, which remains the most fundamental work on the history of private capital in the 1920s, refers to Siberian material [Демчик]; taking into account a considerable number of both published and unpublished sources, it analyses the main stages of the development of private enterprise under the NEP. As for the study of private enterprise in the Urals during the NEP era, the most comprehensive portrait of a NEPman was created by R. A. Khaziev (see: [Хазиев, 2005; Хазиев, 2015] et al.).

Instead of using the chronological principle, Kilin organises the material according to a thematic structure. This makes it possible for the researcher to include private enterprise during the NEP in a wider context. To a large 
extent, this approach was conditioned by the fact that the monograph was written as part of research project 16-18-10106 "Early Soviet Society as a Social Project: Ideas, Realisation Mechanisms, and Construction Results" (academic supervisor: L. N. Mazur), supported by the Russian Science Foundation. This predetermined the author's choice to consider theoretical issues which are not directly related to the topic reflected in the book's title of the book. First of all, Kilin analyses the NEP as a management model, concluding that the NEP was an authoritarian, situational and adaptive model that took into account the agrarian and industrial character of the economy and combined traditional Russian elements and Soviet innovations (c. 29) ${ }^{2}$. The NEP can be characterised as a mixed economy, although regional economic policy had corporate and market features (c. 67).

It is important to point out that the union between the city and the village is not the main focus of the research; however, it is directly connected with the NEP as a whole and a complex analysis of early Soviet society. The union, which is understood as a congruence between the economic interests of the town, the village, the working class and the peasantry, was an illustration of the NEP's motto, which almost turned into a meme. In 1921, the NEP started to turn into a project whose aim was a transition from noneconomic to economic exchange between state industry and petty peasant households. The exchange was supposed to be based on barter rather than monetary principles. Nationwide barter was regarded as a means to both satisfy the needs of the peasantry in manufactured goods and provide urban dwellers with food products.

This experiment was mostly a result of economic dislocation and the malfunction of the monetary system. However, the main reason for the introduction of barter was the Soviet leaders' negative attitude to trade as such. For them, trade was a bearer of "the mark of Cain", reserved for private traders and limited to internal use in districts to meet local demand. According to the theorists of the Bolshevik Party, including Lenin, the development of barter was meant to lead to general distribution, one of the communists' objectives, thereby skipping the stage of trade.

However, the experiment failed quite rapidly, the ones to "blame" being peasants and private traders. Peasants preferred the free money market over barter while private traders took state-permitted cooperation from the local to the inter-district level. As a result, the Soviet state had to sanction the transition to private trade and legalise private capital. In fact, private traders became one of the tools of the union (Rus. смьчка) as they provided the transfer of produce manufactured by state industrial enterprises to the rural consumer. Despite all this, the authorities ignored the fact, ascribing this role to Soviet (state and cooperative) trade. Posters devoted to the "union" (including the one on p. 358 of the book) depicted only workers and peasants. For a NEPman to appear on them was regarded as absolutely impossible.

\footnotetext{
${ }^{2}$ Hereinafter, references to the monograph under review will be provided in parentheses.
} 
In some sections of the book, Kilin considers not only a wider thematical context than that designated by the title but also a wider chronological context. He analyses the peculiarities of commodity turnover in the Urals, the social and psychological aspects of private enterprise in Russia, and a number of some other issues, including references to pre-revolutionary materials. Overall, the monograph refers to historical material directly connected with the history of private trade under the NEP, which, however, is interlaced with theoretical parts.

The author starts the examination of private enterprise in the 1920s by defining its role in the NEP economy and singling out forms of private trade enterprise, product specialisation, and commodity classification of a private trader. The analysis carried out makes it possible for the author to rightfully conclude that the toughening of state policy led private trade to switch to primary commodities and relocate from larger cities to the periphery (c. 213, 234).

Together with this, it is important to make the author's statement that "private enterprise in the Urals, unlike that in the USSR as a whole, did not occupy the leading position in the market" more accurate (c. 213). It does not include any reference to the year, to the types or classification of commodities or their geography. Indeed, in the late 1920s, private trade was not the leading type of trade anywhere, but the situation was drastically different at the beginning of the decade. In 1922 and 1923, private trade accounted for a considerable part of commodity turnover and was the leader when it came to certain kinds of goods. Moreover, the data provided by Kilin testify to the fact that there were no major differences between the state of things in the Ural region and the rest of the country. The share of private traders in intermediate turnover in the USSR for 1926 and 1927 accounted for 18.5 percent, while in the Urals it was $14,9 \%$.

As part of the study of commodity turnover, the book focuses on singling out its peculiarities in the Urals as a region. However, it would have made the work more comprehensive if the author had included data per district. For instance, in the mid-1920s, the southwestern districts of Ural oblast (namely, Kurgan and Ishim) witnessed an intense private butter trade. Despite this, the author mentions the role of the districts in the wholesale trade of butter only once in connection with the purveyance campaign of 1925/26 (c. 343). Additionally, there was private grain procurement in the districts. Still more important for private commodity turnover was Tobolsk District.

The book introduces a considerable number of materials when exploring issues connected with crediting private enterprise. This is the least studied sphere in the national historiography. Kilin provides the general characteristics of the Soviet credit system under the NEP, describing the main principles of crediting private enterprise and offering a detailed analysis of the activity of Mutual Credit Associations and their social composition. He also focuses on the role of credit agencies as an element of the credit sector's infrastructure. When evaluating the activity of the credit system under the NEP, the author points out that it was quickly adapted for the use in market 
conditions. In the late 1920s, it was just as quickly transformed to suit the needs of a centrally planned economy.

An important place in the book is occupied by the analysis of the state regulation of private trade. Here, the author turns to the historiography of the periodisation of the development of trade in the USSR. Unfortunately, Kilin ignores the periodisation proposed by E. V. Demchik, which seems to be the most representative one with regards to private entrepreneurial activity, including trade in the 1920s: 1921-1922/23; 1923/24 - first half of 1924/25; second half of 1924/25-1926; and 1927-1930 [Демчик, с. 204, 239].

When considering the policy of private trade regulation, Kilin provides a brief overview of the "fluctuations of state policy regarding private entrepreneurs" around the USSR without denoting any specific time frame or describing any Ural-specific features. "The "rising stage" of the NEP and private trade is described as being interrupted in 1924/1925. The period between the beginning of 1925 and the end of 1926 is characterised by an intensification of commodity turnover with the active participation of private entrepreneurs. In late 1927, the tendency was to eliminate private enterprise (c. 313-315). Referring to the correlation between the market and administration methods in the economic regulation of private enterprise at different stages of the NEP, the author makes a conclusion which is of crucial importance, i. e. the NEP was a situation model of economic management "with a very short planning period" (c. 317). When faced with another crisis caused by the authorities (resulting from their failure to take into account market-based mechanisms), the state retreated. After this, it "made a leap forward" by means of trial and error method (там же).

Kilin classifies methods of state regulation and provides a more detailed description of some of their peculiarities. Thus, he scrupulously analyses issues underlying the disenfranchisement of private traders, which is regarded not only as a means to limit private enterprise but was also used by the Bolshevik regime as a method of social construction. Of historiographic importance is the source and content analysis of 287 cases of lishentsy (Rus. тишенциь), persons stripped of voting rights, the majority of whom were traders (c. 539).

Together with this, it is important to point out the scarce focus on state and regional policies regarding private trade in agricultural produce. In fact, their description is limited to an example mentioning a ban on the transportation of privately produced butter. In Soviet newspeak, this event was referred to as "economic regulation" (c. 343). This issue is considered in a number of my works which are not mentioned in the references for the book ([Ильиных, 1992; Ильиных, 2005]), etc.

Referring to a step-by-step analysis of the way in which the state regulated the procuring agricultural market of Siberia between 1921 and 1928, I conclude that the degree of anti-market sentiments of the provincial elite was higher than that of the central elite. When taking management decisions, the party, Soviet and economic leaders of the Siberian region proceeded from the need to constantly counteract NEP "outbursts". The regional authorities quite often undermined Moscow's attempts to carry out 
market liberalisation. Thus, starting with 1925, the Siberian Territory Committee of the RCP(B), disregarding V. M. Molotov's orders, kept the ban on the transportation of privately produced grain to regions outside Siberia. Despite A. I. Rykov's dissatisfaction, R. I. Eihe, chairman of the Siberian Territory Committee, justified the arrests of fourteen large grain producers whose "goal was to prevent a complete failure of the collection of grain for the state grain stockpile" [Ильиных, 2005, с. 114, 119, 270]. Unfortunately, it is impossible to either prove or refute this statement with regards to the situation in the Urals. As a result, the Ural authorities seem to have complied strictly with orders from the centre.

Of considerable historiographic importance is the author's description of the tax and law enforcement authorities and their participation in the elimination of private capital in the late 1920s. Certain sections of the book are devoted to the Astrakhan case and its Ural analogue, the case of the Sverdlovsk Regional Financial Department and the campaigns which followed them. These were meant as a purge of the tax authorities and a way to collect debts from private entrepreneurs ("the night of long debts"). As a result of increased pressure from the side of the government, private entrepreneurs formed a so-called closed circle where private enterprise directly interacted with the consumer, leaving out the state. This was perceived by the state as a threat to the Soviet regime and as an attempt to restore capitalism, which led to even harsher measures limiting private enterprise.

A considerable part of the monograph is devoted to the examination of the "social aspects of private entrepreneurship". Before considering the topic, Kilin undertakes an analytical review of Russia's pre-revolutionary past: upon completing this, he makes a rather debatable conclusion about the real social status of the entrepreneurial strata of society. According to him, "the notorious 'relics of the feudal past' gave entrepreneurs a subordinate role in the social hierarchy" (c. 559).

The book considers social aspects of private enterprise under the NEP as part of the analysis of the stratification, identification, and mobility of private traders. The author maintains that as regards private entrepreneurs under the NEP, their social mobility could be characterised as multidirectional. Thus, a marginalised person (e. g. an unemployed or a "former" (Rus. бывшици) person), took a step down in the official Soviet social hierarchy when starting trade and becoming a NEPman. On the other hand, their business activity enabled them to make a profit, which meant going up the hierarchical system based on the amount of money made (c. 560).

Referring to the official division of private traders into fiscal categories, Kilin singles out three main strata of private traders, i. e. petty (patents of the first and second categories), medium (patents of the third category) and large (patents of the fourth and fifth categories). Following some experts of the 1920s, he does not include petty traders in the private capitalist system, characterising them as a category of self-employed producers (small-scale commodity production). Large traders are characterised as representatives of the private capitalist system. The medium group occupies an intermedi- 
ate position. Nationwide, such traders belonged to the private capitalist system of trade, while in the Urals where "private trade was not wide-spread, enterprises of the third category could not always become an important source of capital accumulation" (c. 206).

A number of researchers, however, have a different point of view. E. V. Demchik categorises all private entrepreneurs, including traders, as "capitalist elements", characterising traders in categories 3 to 5 as the "new" bourgeoisie. According to U. Enyuan and V. M. Rynkova, the NEP bourgeoisie only includes traders of the fifth category.

Like his predecessors, Kilin argues that most private traders had not previously participated in any commercial activity. Many of them were forced to turn to petty private trade when they failed to find a job in state and cooperative structures. As for large private traders, the share of "former people" among them was a lot bigger. Petty traders were mostly industrial workers who had lost their jobs, peasants who were looking for a source of income, unemployed clerks and housewives. As for the medium and large groups, they comprised many former employees of trade organisations (salesmen and agents of trade institutions) (c. 507-508).

Analysing the social mobility of private traders, the book's author concludes that the first and third categories of traders were characterised by highly dynamic activity. They were also marked by a high rate of enterprise collapse. The medium group was the most stable one and was constantly replenished by representatives from the other categories. I consider it important to provide additional statistical data to substantiate this fact.

Consequently, I think it would be useful to turn to materials first introduced by L. I. Borodkin and M. A. Svishchev. Having analysed data collected about owners of private trade and industrial enterprises in Ukraine for $1925 / 26$ and 1926/27, they concluded that the lower groups were characterised by a low inter-group mobility (patents of categories 1 and 2). Highercategory patents were chosen by 2,8 and 2,6 \% of the surviving enterprises of the category. This illustrates the marginalised position of petty traders, who did not have an opportunity to improve their status within their respective stratum of entrepreneurs. The number of closed trading establishments in categories 1 and 2 was also high - 38,1 and 37,1\%, respectively. The medium group was relatively stable (patents of category 3): $27,2 \%$ of the enterprises closed, $4 \%$ transferred to the other categories and $4,5 \%$ of representatives from the other categories joined the group. As for enterprises owning patents of the fourth category, 38,6\% of them closed and $11,1 \%$ joined other groups, while the fifth category was characterised by 51,3 and $6,8 \%$ respectively. The least stable group was group 5 , while group 4 was the most mobile [Бородкин, Свищев, с. 109].

When considering petty trade, Kilin points out the fact that it involved some workers of state enterprises who sold cottage industry products made from materials which they stole from their workplaces, things they did not need that they received through the state distribution system and produce from their own gardens. 
One of the book's significant merits is, beyond any doubt, the illustrative material it contains. Of major interest are postcards and caricatures depicting the most typical representatives of the NEP (commissioners, NEPmen, cigarette makers, barterers, shashlik café keepers serving shashlik made from "genuine Siberian cat"): these supplement the author's ideas about the forms of private trade enterprise.

To conclude, it seems important to point out that the author of the monograph opted for the thematic principle when arranging the material instead of the chronological one, thus impeding a more subject-oriented description of the NEP's dynamics. Meanwhile, the NEP was an ever developing (self-organising and self-destroying, as noted ironically by Yu. P. Bokarev [Бокарев, с. 121]) system of economic, political and ideological relations. The first stage of the development of private entrepreneurship under the NEP remains the least-studied and is defined by several researchers as a period of initial accumulation of capital.

It is important to mention, however, that the merits of the work outnumber the disadvantages listed above. Despite its mosaic character, Kilin's work enables the reader to form a comprehensive idea of the NEP and the place of private trade in it. Of great historiographic importance is the author's conclusion about the fact that private enterprise was organically interwoven into the structure of the NEP's mixed economy and served as a bridge between producers, consumers and different sectors of the economy and economic systems (c. 565). Overall, the work is a notable event in the contemporary historiography of the NEP. It does not leave the reader indifferent but rather makes them think and debate, encouraging them to reconsider existing patterns of thinking.

\section{Список литературы}

Бокарев Ю. П. НЭП как самоорганизующаяся и саморазрушающаяся система // НЭП: экономические, политические и социокультурные аспекты. М. : РОССПЭН, 2006. C. 121-133.

Бородкин Л. И., Свищев М. А. Социальная мобильность в период нэпа: к вопросу о росте капитализма из мелкого производства // История СССР. 1990. № 5. С. 105-121.

Демчик E. B. Частный капитал в городах Сибири в 1920-е гг.: от возрождения к ликвидации. Барнаул : Изд-во Алтай. ун-та, 1998. 240 с.

Килин А. П. Частная торговля и кредит на Урале в годы нэпа: экономические, политические и социальные аспекты. Екатеринбург : Изд-во Урал. ун-та, 2018. 606 с.

Ильиных В. А. Коммерция на хлебном фронте : (Государственное регулирование хлебного рынка в условиях нэпа. 1921-1927 гг.). Новосибирск : Наука, 1992. 224 с.

Ильиных $B$. А. Государственное регулирование сельскохозяйственного рынка Сибири в условиях нэпа (1921-1928 гг.). Новосибирск : Изд-во СО РАН, 2005. 284 с.

Орлов И. Б. Нэп в региональном ракурсе: от усредненных оценок к многообразию // НЭП: экономические, политические и социокультурные аспекты. М. : РОССПЭН, 2006. C. 33-54.

Хазиев Р. А. «Ударники капиталистического труда» эпохи нэпа на Урале // Бублики для республики: исторический профиль нэпманов. Уфа : РИО БашГУ, 2005. 224 с.

Хазиев Р. А. Частный капитал Башкирии в эпоху нэпа : «Что значит быть советским предпринимателем в провинции» // Вестн. Башкир. ун-та. 2015. № 3. С. 1122 1128. 


\section{References}

Bokarev, Yu. P. (2006). Nep kak samoorganizuyushchayasya i samorazrushayushchayasya sistema [The NEP as a Self-Organising and Self-Destroying System]. In NEP: ekonomicheskie, politicheskie i sotsiokul 'turnye aspekty. Moscow, ROSSPEN, pp. 121-133.

Borodkin, L. I., Svishchev, M. A. (1990). Sotsial'naya mobil'nost' v period nepa: k voprosu o roste kapitalizma iz melkogo proizvodstva [Social Mobility under the NEP: On the Development of Capitalism from Petty Production]. In Istoriya SSSR. No. 5, pp. 105-121.

Demchik, E. V. (1998). Chastnyi kapital v gorodakh Sibiri v 1920-e gg.: ot vozrozhdeniya k likvidatsii [Private Capital in Siberian Cities in the 1920s]. Barnaul, Izdatel'stvo Altaiskogo universiteta. $240 \mathrm{p}$.

Il'inykh, V. A. (1992). Kommertsiya na khlebnom fronte: (Gosudarstvennoe regulirovanie khlebnogo rynka v usloviyakh nepa. 1921-1927 gg.) [Commerce on the Grain Market: (State Regulation of the Grain Market under the NEP. 1921-1927)]. Novosibirsk, Nauka. 224 p.

Il'inykh, V. A. (2005). Gosudarstvennoe regulirovanie sel'skokhozyaistvennogo rynka Sibiri v usloviyakh nepa (1921-1928 gg.) [State Regulation of the Agricultural Market of Siberia under the NEP (1921-1928)]. Novosibirsk, Izdatel'stvo Sibirskogo otdeleniya RAN. 284 p.

Khaziev, R. A. (2015). Chastnyi kapital Bashkirii v epokhu nepa: "Chto znachit byt' sovetskim predprinimatelem v provintsii" [Private Capital of Bashkiria under the NEP: "What it Means to be a Soviet Entrepreneur in the Province"]. In Vestnik Bashkirskogo universiteta. No. 3, pp. 1122-1128.

Khaziev, R. A. "Udarniki kapitalisticheskogo truda" epokhi nepa na Urale [Udarniks of Capitalist Labour under the NEP in the Urals]. In Bubliki dlya respubliki: istoricheskii profil'nepmanov. Ufa, RIO Bashkirskogo gosudarstvennogo iniversiteta. $224 \mathrm{p}$.

Kilin, A. P. (2018). Chastnaya torgovlya i kredit na Urale v gody nepa: ekonomicheskie, politicheskie $i$ sotsial'nye aspekty [Private Trade and Credit in the Urals under the NEP: Economic, Political, and Social Aspects]. Yekaterinburg, Izdatel'stvo Ural'skogo universiteta. $606 \mathrm{p}$.

Orlov, I. B. (2006). Nep v regional'nom rakurse: ot usrednennykh otsenok k mnogoobraziyu [The NEP through the Regional Perspective: From Averages to Diversity]. In NEP: ekonomicheskie, politicheskie i sotsiokul'turnye aspekty. Moscow, ROSSPEN, pp. 33-54.

Translated by Tatiana Kuznetsova

The article was submitted on 15.12.2019 